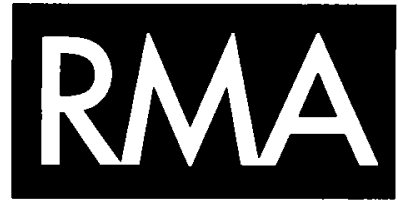

ISSN 1472-3808

$\overline{\text { ROYAL MUSICAL ASSOCIATION }}$

\title{
Royal Musical
}

Association

RESEARCH CHRONICLE

\section{9: 2006}

Edited by Jonathan P. Wainwright

Allan W. Atlas Ladies in the Wheatstone Ledgers: the Gendered Concertina in Victorian England, 1835-1870 